\title{
PENGARUH PEMBERIAN VITAMIN C, VITAMIN E, DAN KROMIUM (CR3+) TERHADAP KADAR INSULIN TIKUS WISTAR YANG DIINDUKSI ALOKSAN
}

\author{
Anugrah Linda Mutiarani \\ Staf Pengajar Gizi Fakultas Kesehatan,Universitas Nahdlatul Ulama Surabaya \\ Email: Anugrahlinda87@unusa.ac.id
}

\begin{abstract}
Objective: To analyze the effect of vitamin $\mathrm{C}$, vitamin $\mathrm{E}$, and chromium $(\mathrm{Cr} 3+)$ on insulin levels Wistar rats were induced alloxan.Materials and Methods: This study is an experimental laboratory. Using rats type Wistar strain Rattus novergicus for 6 weeks with a number of 20 head. The independent variables consist of 5 treatment groups namely normal diet, normal diet $+1 \mathrm{~g} / \mathrm{hr}$ chromium, normal diet $+2 \mathrm{mg} /$ day of vitamin $\mathrm{C}$, normal diet $+0.5 \mathrm{mg}$ /day of vitamin $\mathrm{E}$, normal diet $+1 \mathrm{~g} / \mathrm{hr}$ chromium $+2 \mathrm{mg}$ /day of vitamin $\mathrm{C}+0.5$ $\mathrm{mg}$ /day of vitamin E. The dependent variable is the level of insulin. To know the differences of each treatment used statistical tests One Way ANOVA, followed by Tukey HSD Post Hoc test with $\mathrm{p}<0.05$. Results: There were significant differences in insulin levels $(\mathrm{p}<0.05)$ in the control group, 1,2 , and 4 . But in the control group and the group 3 there are no significant differences in insulin levels $(\mathrm{p}=0.145)$. Conclusion: Delivery of chromium (treatment 1), vitamin $C$ (treatment 2), and a mixture of chromium, vitamin $\mathrm{C}$, vitamin $\mathrm{E}$ (treatment 4 ) effect on insulin levels, while administration of vitamin $\mathrm{E}$ (treatment 3 ) alone had no effect on insulin levels
\end{abstract}

Keywords: Insulin Levels, Chromium, Vitamin C, Vitamin E

\section{PENDAHULUAN}

Diabetes Mellitus merupakan suatu kelompok penyakit metabolik dengan karakteristik hiperglikemia yang terjadi karena kelainan sekresi insulin, kerja insulin, atau kedua-duanya (Perkeni, 2011). International Diabetes Federation (IDF) pada tahun 2013 menyatakan bahwa jumlah penderita diabetes terus meningkat tiap tahunnya, saat ini di seluruh dunia pendertia diabetes mellitus mencapai 382 juta orang dan diperkirakan meningkat pada tahun 2035 menjadi 592 juta orang. Selain itu laporan IDF menunjukkan Indonesia merupakan negara ke-7 terbesar untuk prevalensi diabetes mellitus. Berdasarkan hasil Riskesdas (2013), di Indonesia secara keseluruhan lebih dari 33,6\% penduduk mengalami keadaan gula darah puasa yang terganggu dan 29,9\% mengalami keadaan toleransi glukosa terganggu yang artinya kondisi ini memiliki risiko tinggi untuk berkembang menjadi diabetes mellitus.

Pada penderita diabetes mellitus, terjadi disfungsi pada sel $\beta$ pankreas dan menurunnya respon insulin terhadap jaringan (hati, lemak, dan otot) atau resistensi insulin (British Nutrition Foundation, 2013). Dengan demikian pendekatan terbaik untuk pengobatan diabetes mellitus adalah dengan memperbaiki resistensi insulin dan fungsi sel $\beta$ pankreas.

Penurunan fungsi sel $\beta$ pankreas menyebabkan kondisi gula darah yang tinggi di dalam darah (hiperglikemia). Kondisi hiperglikemia mengakibatkan peningkatan radikal bebas di dalam sel dan pada jumlah yang berlebihan dapat bersifat toksik yang mendorong terjadinya stres oksidatif sehingga dapat terbentuk Reactive Oxygen Species (ROS) atau Reactive Nitrogen Species (RNS) (Desminarti, dkk, 2012).

Salah satu mikronutrien yang berperan didalam pengaturan gula darah adalah kromium yang merupakan kofaktor dalam meningkatkan kerja insulin dalam pemindahan glukosa ke dalam sel (Unjiati, 2014). Menurut Lingga (2012) kromium sangat penting untuk mengatasi resistensi insulin dan menurunkan kadar gula darah. Selain kromium, 
vitamin $\mathrm{C}$ dan vitamin $\mathrm{E}$ merupakan antioksidan yang berfungsi menangkap radikal bebas serta mencegah terjadinya reaksi berantai. Vitamin $\mathrm{C}$ berfungsi sebagai agen pereduksi (donor elektron) radikal bebas dan menonaktifkannya, sementara vitamin $\mathrm{C}$ sendiri menjadi radikal askorbil. Radikal ini kemudian didaur ulang kembali menjadi askorbat menggunakan glutation tanpa menyebabkan kerusakan oksidatif. Vitamin E sebagai tokoferol berfungsi mencegah peroksidasi membran fosfolipid. Tokoferol $\mathrm{OH}$ dapat memindahkan atom hidrogen dengan satu elektron ke radikal bebas dan membersihkan radikal bebas sebelum radikal bebas bereaksi dengan protein membran sel atau bereaksi membentuk lipid peroksidasi (Barasi, 2009).

Berdasarkan uraian diatas menunjukkan bahwa vitamin $\mathrm{C}$, vitamin $\mathrm{E}$, dan kromium mempunyai peranan yang penting dalam penangan diabetes mellitus. Oleh karena itu, penelitian ini bertujuan untuk mengetahui pengaruh pemberian vitamin $\mathrm{C}$, vitamin E, dan kromium terhadap kadar insulin tikus wistar yang diinduksi aloksan.

\section{BAHAN DAN METODE}

\section{RANCANGAN PENELITIAN}

Penelitian ini merupakan penelitian true eksperimental yang dilakukan menggunakan desain eksperimental laboratorik dengan pendekatan Randomized Pre-Post Test With Control Group Design. Dengan rancangan ini, memungkinkan peneliti mengukur pengaruh perlakuan (intervensi) pada kelompok eksperimen dengan cara membandingkan kelompok eksperimen dangan kelompok kontrol (Notoatmodjo, 2005).

\section{SAMPEL PENELITIAN}

Sampel pada penelitian ini menggunakan tikus putih jantan jenis Rattus Novergicus galur Wistar berjumlah 20 ekor. Usia tikus adalah 2-3 bulan dengan berat badan 100-200 gram serta tidak pernah digunakan dalam penelitian sebelumnya. Hewan coba diperoleh dari Laboratorium Biokimia Fakultas Kedokteran Universitas Airlangga Surabaya.

\section{VARIABEL PENELITIAN}

Variabel independen terdiri dari 5 kelompok perlakuan yaitu diet normal (P0), diet normal +1 $\mu \mathrm{g} / \mathrm{hr}$ kromium (P1), diet normal $+2 \mathrm{mg} / \mathrm{hr}$ vitamin $\mathrm{C}(\mathrm{P} 2)$, diet normal $+0,5 \mathrm{mg} / \mathrm{hr}$ vitamin $\mathrm{E}(\mathrm{P} 3)$, diet normal $+1 \mu \mathrm{g} / \mathrm{hr}$ kromium $+2 \mathrm{mg} / \mathrm{hr}$ vitamin $\mathrm{C}+$ $0,5 \mathrm{mg} / \mathrm{hr}$ vitamin $\mathrm{E}(\mathrm{P} 4)$, sedangkan variabel dependen adalah kadar insulin.

\section{PENENTUAN DOSIS PERLAKUAN}

Pemberian dosis pada masing-masing kelompok perlakuan berdasarkan Angka Kecukupan Gizi orang Indonesia Tahun 2012 yang dikonversikan untuk tikus. Berdasarkan penelitian Yuliani, dkk (2011) menyebutkan bahwa angka konversi manusia ke tikus wistar (200 gram) adalah 0,018, sehingga penentuan dosis kromium, vitamin $\mathrm{C}$, dan vitamin $\mathrm{E}$ adalah sebagai berikut :

1. Kebutuhan kromium manusia sehari sebesar 35 $\mu \mathrm{g} / \mathrm{hr}$ (AKG, 2012), maka dosis pada tikus adalah $35 \mu \mathrm{g} / \mathrm{hr}$ x $0,018=0,63 \mu \mathrm{g} / \mathrm{hr} \sim 1 \mu \mathrm{g} / \mathrm{hr}$.

2. Kebutuhan vitamin $\mathrm{C}$ manusia sehari sebesar 90 $\mathrm{mg} / \mathrm{hr}$ (AKG, 2012), maka dosis pada tikus adalah $90 \mathrm{mg} / \mathrm{hr} \times 0,018=1,62 \mathrm{mg} / \mathrm{hr} \sim 2 \mathrm{mg} / \mathrm{hr}$

3. Kebutuhan vitamin $\mathrm{E}$ manusia sehari adalah 15 $\mathrm{mg} / \mathrm{hr}$ (AKG, 2012), maka dosis pada tikus adalah $15 \mathrm{mg} / \mathrm{hr} \times 0,018=0,27 \mathrm{mg} / \mathrm{hr} \sim 0,5$ $\mathrm{mg} / \mathrm{hr}$ dan $1 \mathrm{mg} \alpha$ tokoferol $=1,49 \mathrm{IU}$ vitamin $\mathrm{E}$, maka $0,5 \mathrm{mg}$ vitamin $\mathrm{E}=1,49 \times 0,5=0,745$ $\mathrm{IU} / \mathrm{hr} \sim 0,75 \mathrm{IU} / \mathrm{hr}$

4. Pembuatan Tikus Wistar Diabetes Mellitus

5. Setelah pemberian perlakuan selama 40 hari, tikus yang akan diinduksi aloksan ditimbang untuk diketahui berat badannya. Untuk membuat tikus putih wistar menjadi diabetes yaitu dengan menginduksikan aloksan secara intraperitonial yang mengacu pada penelitian Putri (2014) yaitu 30 mg/150 gram BB tikus. Tanda-tanda Diabetes Melitus diperoleh jika kadar gula darah tikus $>150 \mathrm{mg} / \mathrm{dL}$.

\section{PERLAKUAN PADA HEWAN COBA}

Perlakuan pada hewan coba berupa tikus putih berjumlah 20 ekor ditimbang dan dicatat berat badannya, selanjutnya dilakukan pemeriksaan kadar gula darah awal sebelum perlakuan, setelah tikus dinyatakan memiliki gula darah normal $(<150$ $\mathrm{mg} / \mathrm{dl})$ maka dilakukan pengacakan untuk 
menempatkan pada kandang perlakuan sesuai dengan rancangan percobaan yang digunakan. Tikus diadaptasikan dalam kondisi sama selama enam hari dalam kandang beralaskan sekam. Tikus jantan dalam satu kandang berisi 4 ekor yang tidak memerlukan penyekat, karena tidak berkelahi. Pakan yang diberikan berupa pakan normal (confeed PARS 69,23\% + tepung terigu 30,77\% + air secukupnya) sebesar 20 gram/hari dan diberikan minum berupa air kemasan yang diberikan secara ad libitum. Setelah dilakukan adaptasi, tikus tersebut dibagi menjadi 5 kelompok perlakuan sehingga tiap kelompok terdiri dari 4 ekor. Masingmasing perlakuan dilaksanakan selama 40 hari, kemudian pada hari ke 41 tikus diinduksi menggunakan aloksan dan ditunggu selama 3 hari, kemudian pada hari ke 43 diperiksa kadar insulinnya.

\section{PEMERIKSAAN KADAR INSULIN}

Pengukuran kadar insulin menggunakan rat ELISA kit dalam satuan $\mathrm{ng} / \mathrm{ml}$, dimana serum tikus diambil dari intrakardial (jantung).

\section{PENGOLAHAN DAN ANALISA DATA}

Data yang diperoleh akan dianalisa secara statistik menggunakan uji beda yang didahului dengan uji normalitas data, apabila distribusi data normal maka dilanjutkan dengan uji statistik "One Way Anova". Kemudian data diolah secara komputerisasi dengan menggunakan program SPSS 16. One way Anova ini digunakan karena perlakuan pada sampel lebih dari satu, selain itu juga digunakan untuk mengetahui homogenitas sampel. Hasil yang ada menggambarkan berbeda makna atau tidak.

Jika ada perbedaan maka dilanjutkan dengan uji Post Hoc Tukey untuk melihat perbedaan dari tiap kelompok. Batas derajat kemaknaan yang akan dicapai adalah $\mathrm{p}<0,05$.

\section{HASIL PENELITIAN}

Setelah Perlakuan, tikus wistar diinjeksi aloksan pada hari ke 41 kemudian pada hari ke 43 dilakukan pengukuran kadar insulin pada masing-masimg tikus wistar. Rerata kadar insulin dapat dilihat pada tabel 1 berikut ini:
Tabel 1: Rerata dan Standar Deviasi Variabel Kadar Insulin (ng/dl) Pada Semua Kelompok

\begin{tabular}{ll}
\hline Kelompok & Sesudah \\
\hline Kelompok Kontrol & $8,80 \pm 3,67$ \\
\hline Kelompok Kromium & $20,76 \pm 1,452$ \\
\hline Kelompok Vitamin C & $18,27 \pm 3,325$ \\
\hline Kelompok Vitamin E & $15,27 \pm 4,562$ \\
\hline $\begin{array}{l}\text { Kelompok Kromium, } \\
\text { Vitamin C, Vitamin E }\end{array}$ & $24,25 \pm 4,456$ \\
\hline
\end{tabular}

Pada Tabel 1 menunjukkan rerata kadar insulin pada masing-masing kelompok. Untuk melihat perubahan rerata kadar insulin tersebut dapat dilihat pada Gambar 1.

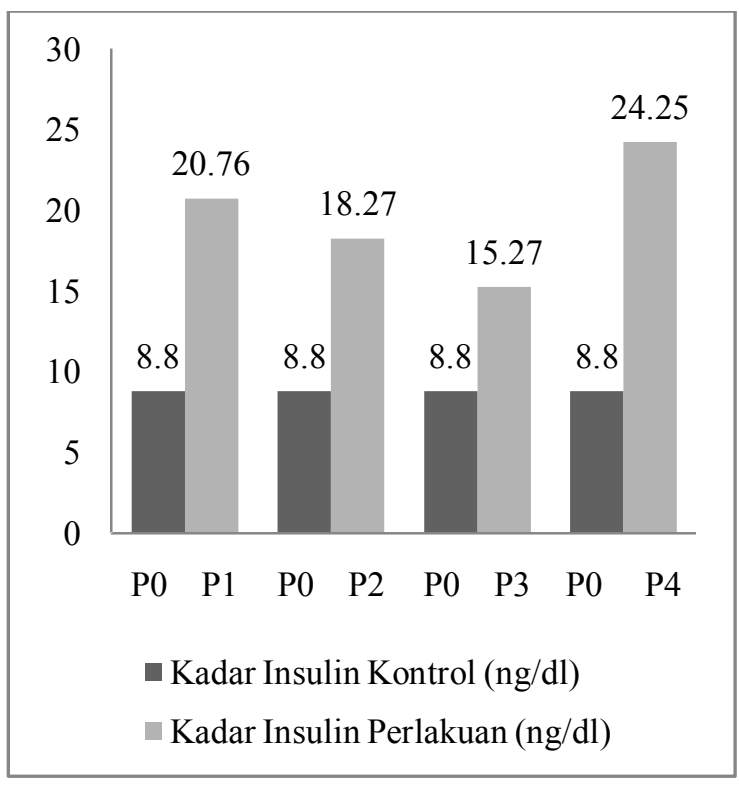

Gambar 1. Perubahan Rerata Kadar Insulin Tikus Wistar

Keterangan: P0: Tikus dengan diet normal, P1: Tikus dengan diet normal + kromium, P2: Tikus dengan diet normal + vitamin C, P3: Tikus dengan diet normal + vitamin E, P4: Tikus dengan diet normal + kromium + vitamin $\mathrm{C}+$ vitamin $\mathrm{E}$

Berdasarkan Gambar 1 diketahui bahwa perubahan rerata kadar insulin terhadap kontrol paling tinggi adalah kelompok kromium, vitamin $\mathrm{C}$, dan vitamin E yaitu sebesar 15,45 ng/dl, sedangkan perubahan rerata kadar insulin terhadap kontrol yang paling rendah adalah kelompok vitamin $\mathrm{E}$ yaitu sebesar $6,47 \mathrm{ng} / \mathrm{dl}$. 


\section{UJI NORMALITAS INSULIN}

Untuk menguji perbedaan kadarinsulin antara kelompok kontrol (diet normal) dengan kelompok perlakuan, perlu dilakukan uji normalitas terlebih dahulu menggunakan uji Kolmogorov Smirnov. Hasil uji normalitas kadar insulin adalah sebagai berikut:

Tabel 2. Hasil Uji Normalitas Kadar Insulin Tikus Wistar

\begin{tabular}{lll}
\hline No & Kelompok & P value \\
\hline 1 & Kelompok Kontrol & 0,994 \\
\hline 2 & Kelompok Kromium & 0,956 \\
\hline 3 & Kelompok Vitamin C & 0,998 \\
\hline 4 & Kelompok Vitamin E & 0,993 \\
\hline 5 & $\begin{array}{l}\text { Kelompok Kromium, } \\
\text { Vitamin C, Vitamin E }\end{array}$ & 0,965 \\
\hline
\end{tabular}

Dari hasil diatas dapat diketahui bahwa uji normalitas kadar insulin pada masing-masing kelompok memiliki nilai $\mathrm{p}>\alpha$ yang artinya data kadar insulin terdistribusi normal.

\section{PERBEDAAN KADAR INSULIN ANTARA KELOMPOK PERLAKUAN DAN KELOMPOK KONTROL}

Untuk menguji perbedaan kadar insulin antara kelompok perlakuan dengan kelompok kontrol dilakukan uji One Way ANOVA dan didapatkan hasil $p<0,05$. Selanjutnya dilakukan uji Post Hoc Tukey untuk masing-masing variabel yang dapat dilihat pada Tabel 3 .

Tabel 3. Hasil Uji Post Hoc Tukey Kadar Insulin Kelompok Perlakuan dengan Kelompok Kontrol

\begin{tabular}{lll}
\hline No & Kelompok & P value \\
\hline 1 & Kelompok Kromium & 0,003 \\
\hline 2 & Kelompok Vitamin C & 0,017 \\
\hline 3 & Kelompok Vitamin E & 0,145 \\
\hline 4 & $\begin{array}{l}\text { Kelompok Kromium, } \\
\text { Vitamin C, Vitamin E }\end{array}$ & 0,000 \\
\hline
\end{tabular}

Dari Tabel 3 diatas dapat disimpulkan bahwa antara kelompok perlakuan dengan kelompok kontrol terdapat perbedaan yang bermakna yaitu $p<0,05$, kecuali untuk kelompok vitamin $\mathrm{E}$ tidak terdapat perbedaan yang bermakna $p>0,05(p=0,145)$.

Sehingga dapat dikatakan bahwa kelompok kromium, vitamin $\mathrm{C}$, dan kelompok campuran dari kromium, vitamin $\mathrm{C}$, dan vitamin $\mathrm{E}$ memiliki pengaruh terhadap kadar insulin. Sedangkan kelompok vitamin $\mathrm{E}$ tidak memiliki pengaruh terhadap kadarinsulin.

\section{PEMBAHASAN}

Diabetes mellitus merupakan sekumpulan sindrom heterogen yang ditandai dengan peningkatan glukosa darah puasa yang disebabkan oleh defisiensi insulin relatif atau absolut (Champe, et al., 2010).

Kondisi ini menyebabkan glukosa yang masuk ke dalam sel berkurang. Akibatnya, sel kekurangan glukosa sehingga kemungkinan tidak terjadi penimbunan glikogen. Sebaliknya, akan terjadi mobilisasi cadangan glikogen di hati mau pun di otot untuk dikatabolisme menghasilkan glukosa dan dilepas ke pembuluh darah sehingga menyebabkan kondisi hiperglikemia. Hiperglikemia kronis pada diabetes melitus akan disertai dengan kerusakan, gangguan fungsi beberapa organ tubuh khususnya mata, ginjal, saraf, jantung, dan pembuluh darah (Suarsana, dkk., 2010).

Diabetes mellitus merupakan penyakit dengan prevalensi yang diprediksi akan terus meningkat tiap tahunnya, sehingga hal ini membuktikan bahwa penyakit diabetes mellitus merupakan masalah kesehatan masyarakat. penyakit ini merupakan faktor resiko utama terjadinya komplikasi penyakit yang lain

\section{PENGARUH PEMBERIAN KROMIUM TERHADAP KADAR INSULIN}

Hasil penelitian menunjukkan bahwa selisih rerata kadar insulin terhadap kelompok kontrol cukup tinggi yaitu sebesar 11,96 ng/dl. Selain itu, berdasarkan hasil penelitian menyatakan pula bahwa ada perbedaan antara kelompok kromium dan kelompok kontrol dengan nilai $\mathrm{p}<\alpha(\mathrm{p}=0,003)$. Sehingga dapat disimpulkan bahwa pemberian kromium memberikan pengaruh terhadap kadar insulin tikus wistar. 
Fungsi kromium di dalam tubuh adalah transformasi kromium menjadi bentuk aktif biologis yang disebut GlucoseTolerance Factor (GTF) yang merupakan suatu kompleks metalloprotein yang terbentuk dari oligopeptida chromodulin, yang terdiri dari empat residu asam amino, yaitu aspartat, sistein, glutamate, dan glisin, terikat dengan empat pusat kromium.

Studi tentang mekanisme kerja kromium menunjukkan adanya suatu biomolekul yang mengandung kromium, yaitu LMWCr (Low Molecular Weight-Chromium binding substance), yang disebut kromodulin. Kromodulin tersusun oleh oligopeptida dari glisin, sistein, aspartat dan glutamat bersama kromium. Kromodulin berperan untuk melakukan aktivasi reseptor insulin kinase. Ikatan kompleks kromodulin berikatan dengan reseptor insulin dan menjaganya agar tetap dalam kondisi yang aktif sehingga meningkatkan masuknya glukosa ke dalam sel (Olivia J.P., 2010; Unjiati, 2014). Perkiraan mekanisme transport kromium didalam tubuh adalah kromium disimpan di dalam darah dalam bentuk terikat pada transferin, kompleks kromium-transferin terhubungkan dengan transferin reseptor dan masuk ke dalam sel. Jika glukosa darah meningkat atau insulin disekresi maka akan meningkatkan kromium ke dalam plasma (Linder, 2006).

Mekanisme peran kromium adalah menfasilitasi interaksi insulin dengan reseptor ketika glukosa masuk di permukaan sel. sehingga hal ini dapat menurunkan resiko terjadinya penyakit diabetes mellitus.

Akan tetapi pada penelitian ini menunjukkan bahwa setelah dilakukan injeksi aloksan tetap terjadi penurunan kadar insulin pada masing-masing tikus wistar, hanya saja pada kelompok kromium memiliki penurunan kadar insulin yang cukup rendah dibandingkan kelompok kontrol.

\section{PENGARUH PEMBERIAN VITAMIN C TERHADAP KADAR INSULIN}

Hasil penelitian menunjukkan bahwa hasil selisih rerata kadar insulin terhadap kelompok kontrol yaitu sebesar 9,47 ng/dl. Selain itu, berdasarkan hasil penelitian menyatakan pula bahwa ada perbedaan antara kelompok vitamin $\mathrm{C}$ dan kelompok kontrol dengan nilai $\mathrm{p}<\alpha(\mathrm{p}=0,017)$. Sehingga dapat disimpulkan bahwa pemberian vitamin $\mathrm{C}$ memberikan pengaruh terhadap kadar insulin tikus wistar.

Meningkatnya kadar glukosa darah akibat pemberian aloksandapat disebabkan oleh dua hal yaitu terbentuknya radikal bebas dan terganggunya permeabilitas membran sel yang mengakibatkan terjadinya kerusakan sel beta pankreas penghasil insulin. Peran insulin adalah mendorong glukosa masuk ke dalam sel untuk di metabolisme, tetapi karena sel beta rusak maka glukosa tidak dapat dimetabolisme, melainkan tertumpuk di dalam darah (Winarsi, dkk, 2013)

Insulin merupakan hormon protein yang berinteraksi dengan reseptor sel organ target untuk meningkatkan permeabilitas membran sel terhadap glukosa, sehingga glukosa dapat masuk ke dalam sel-sel otot (disimpan sebagai glikogen), dan juga ke dalam sel jaringan lemak (disimpan sebagai trigliserida).

Penelitian sebelumnya yang dilakukan oleh Wulandari, dkk (2014) menyebutkan adanya penurunan kadar vitamin $\mathrm{C}$ dalam DM tipe 2 . Vitamin C secara struktural mirip dengan glukosa, dan dapat menggantikan glukosa dalam berbagai reaksi kimia, sehingga efektif untuk pencegahan glikosilasi protein non-enzimatik.

Asam askorbat (vitamin C), antioksidan non enzimatis, berperan penting dalam melindungi kerusakan sel akibat radikal bebas yaitu auto oksidasi glukosa, glikosilasi protein yang terlibat dalam pembentukan stress oksidatif dan etiologi terjadinya diabetes mellitus. Vitamin C mengurangi toksisitas glukosa yang berkontribusi mencegah penurunan massa sel $\beta$ dan kadar insulin. Berkurangnya kadar glukosa darah karena vitamin C plasma berperan dalam modulasi kerja insulin pada penderita diabetes. Peningkatan kerja insulin yang dimediasi vitamin $\mathrm{C}$ terutama disebabkan oleh peningkatan metabolisme glukosa non-oksidatif. (Winarsi, dkk, 2013)

Akan tetapi pada penelitian ini tetap menunjukkan bahwa setelah dilakukan injeksi aloksan tetap terjadi penurunan kadar insulin pada masing-masing tikus wistar, hanya saja pada kelompok vitamin $\mathrm{C}$ memiliki penurunan kadar 
insulin yang cukup rendah jika dibandingkan dengan kontrol.

\section{PENGARUH PEMBERIAN VITAMIN E TERHADAP KADAR INSULIN}

Hasil penelitian menunjukkan bahwa hasil selisih rerata kadar insulin terhadap kelompok kontrol yaitu sebesar 6,47 ng/dl. Selain itu, berdasarkan hasil penelitian menyatakan pula bahwa tidak ada perbedaan antara kelompok vitamin $\mathrm{E}$ dan kelompok kontrol dengan nilai $\mathrm{p}>\alpha$ $(p=0,145)$. Sehingga dapat disimpulkan bahwa pemberian vitamin $\mathrm{E}$ tidak memberikan pengaruh terhadap kadar insulin tikus wistar.

Diabetes pada hewan percobaan yang diinduksi oleh aloksan, terjadi karena gangguan sekresi insulin disebabkan oleh kerusakan sel $B$ pankreas oleh akumulasi radikal bebas dari aloksan. Penghilangan atau pengurangan radikal bebas (efek antioksidatif) pada sel $\beta$ kemungkinan dapat menurunkan kerusakan sel $\beta$ dan memperbaiki fungsi insulin sehingga kadar glukosa darah pada tikus diabetes dapat diturunkan (efek hipoglisemik).

Vitamin E merupakan antioksidan yang berperan penting di dalam melindungi susunan lipida di dalam sel mitokondria dari kerusakan oksidasi. Proses peroksidasi lipid dapat menyebabkan terjadinya kerusakan fungsi sel dan struktur dari membran sel. Membran sel terdiri dari asam lemak tidak jenuh ganda yang mudah dioksidasi oleh radikal bebas. (Bender, 2010)

Vitamin E teroksidasi sangat lambat sehingga memberikan peran yang sangat baik sebagai antioksidan. Dalam kerjanya sebagai antioksidan, vitamin $\mathrm{E}$ menonaktifkan radikal bebas yang menyerang jaringan dan mencegah oksidasi dari asam lemak tidak jenuh. (Schlenker dan Roth, 2011)

Tetapi pada penelitian ini, vitamin E tidak memiliki pengaruh terhadap kadar glukosa darah maupun kadar insulin. Hal ini mungkin terjadi karena vitamin E bekerja sendiri sebagai antioksidan. Kumalingsih (2007) menyatakan bahwa kombinasi beberapa jenis antioksidan memberikan perlindungan yang lebih baik(sinergisme) terhadap oksidadi dibandingkan dengan satu jenis antioksidan saja.
Vitamin E perlu bantuan vitamin C untuk menstabilkan kembali radikal tokoferoksil. Hal ini sejalan dengan Barasi (2009) bahwa Vitamin E (sebagai tokoferol) dapat menyumbangkan satu hidrogen ke radikal lipid peroksil, untuk menghasilkan lipid hidroperoksida dan radikal tokoferoksil. Radikal tokoferoksil sukar bereaksi, sehingga membutuhkan vitamin $\mathrm{C}$ atau glutation untuk mendaur ulang radikal ini menjadi tokoferol dan dapat berfungsi kembali sebagai antioksidan.

Dapat disimpulkan bahwa pada penelitian ini vitamin $\mathrm{E}$ tidak berbeda nyata atau berpengaruh terhadap kadar glukosa darah dan insulin tikus wistar. Dalam kerjanya sebagai antioksidan, vitamin E perlu dikombinasi dengan konsumsi vitamin $\mathrm{C}$ sebagai penstabil radikal yang terbentuk secara alami dari vitamin E, sehingga vitamin E dapat menjalankan fungsinya kembali sebagai antioksidan

\section{PENGARUH PEMBERIAN KROMIUM, VITAMIN C, DAN VITAMIN ETERHADAP KADAR INSULIN}

Selisih rerata kadar insulin terhadap kelompok kontrol yaitu sebesar 15,45 ng/dl. Berdasarkan hasil penelitian menunjukkan bahwa ada perbedaan antara kelompok kromium, vitamin $\mathrm{C}$, dan vitamin $\mathrm{E}$ dan kelompok kontrol dengan nilai $\mathrm{p}<\alpha$ $(\mathrm{p}=0,000)$. Sehingga dapat disimpulkan bahwa terdapat pengaruh pemberian kromium, vitamin $\mathrm{C}$, dan vitamin E secara bersama terhadap kadar insulin tikus wistar.

Hiperglikemi akan terjadi sesuai dengan derajat kerusakan sel beta yang menyebabkan turunnya sekresi insulin. Pelepasan insulin dari sel beta pankreas sangat tergantung pada transpor glukosa melewati membran sel dan interaksinya dengan sensor glukosa yang akan menginduksi peningkatan glukokinase. Bila glukosa plasma tinggi maka sekresi insulin secara normal meningkat dan glukogenesis hati juga meningkat

Kromium dalam bentuk suplemen maupun makanan paling banyak dalam bentuk trivalen yang merupakan bentuk paling stabil. Kromium mempunyai fungsi meningkatkan kerja biologis insulin. Penyerapan kromium berbanding terbalik dengan proporsi kromium yang dikonsumsi karena penyerapan tubuh terhadap kromium dari makanan 
sangat rendah. Pada penelitian Cefalu dan $\mathrm{Hu}, 2004$ dalam Unjiati, 2014 menyebutkan bahwa ada beberapa faktor yang menghambat penyerapan kromium yaitu konsumsi itat dan glukosa, sedangkan penambahan vitamin $\mathrm{C}$, asam amino, oksalat dapat membantu penyerapan kromium.

Barasi (2009) menyatakan bahwa Vitamin E (sebagai tokoferol) dapat menyumbangkan satu hidrogen ke radikal lipid peroksil, untuk menghasilkan lipid hidroperoksida dan radikal tokoferoksil. Radikal tokoferoksil sukar bereaksi, sehingga membutuhkan vitamin $\mathrm{C}$ atau glutation untuk mendaur ulang radikal ini menjadi tokoferol dan dapat berfungsi kembali sebagai antioksidan.

Pada hasil penelitian ini menunjukkan bahwa penggunaan secara bersama kromium, vitamin $\mathrm{C}$, dan vitamin $\mathrm{E}$ berpengaruh yang paling efektif terhadap kadar insulin serum dibandingkan dengan penggunaan kromium, vitamin $\mathrm{C}$, maupun vitamin secara terpisah.

Penggunaan secara bersama kromium, vitamin C, dan vitamin $\mathrm{E}$ dapat lebih mudah dalam melumpuhkan radikal bebas, sehingga pengurangan radikal bebas (efek antioksidatif) pada sel $\beta$ kemungkinan dapat menurunkan kerusakan sel $\beta$ dan memperbaiki fungsi insulin sehingga kadar glukosa darah pada tikus diabetes.

\section{KESIMPULAN}

1. Perlakuan yang paling efektif terhadap kadar insulin tikus wistar adalah dengan pemberian kromium, vitamin C, vitamin E secara bersamasama

2. Ada perbedaan secara bermakna kadar insulin tikus wistar antara kelompok kontrol dan kelompok perlakuan, kecuali pada kelompok perlakuan vitamin $\mathrm{E}$

\section{SARAN}

Perlu dilakukan penelitian lanjutan dengan dosisvitamin $\mathrm{C}$, vitamin $\mathrm{E}$ dan kromium yang lebih tinggi dan jangka waktu yang lebih lama.

\section{DAFTAR PUSTAKA}

Barasi, Mary E., 2009. At a Glance Ilmu Gizi. Jakarta: Penerbit Erlangga
Bender. D. A. 2010. Nutritional Biochemistry of The Vitamins. New York. Cambridge University Press.

British Nutrition Foundation, 2013. Nutrition and development: short an long term consequences for your health. British: blackwell publishing Ltd.

Champe, Pamela C, et al., 2010. Biokimia Ulasan Bergambar. Jakarta: EGC

Desminarti, Susi (dkk). 2012. Efek Bubuk Tempe Instan Terhadap Kadar Malonaldehid (MDA) Serum Tikus Hiperglikemik. Jurnal Kedokteran Hewan. ISSN: 1978-225X. Vol. 6 No. 2, September 2012

IDF 2013. Diabetic Atlas. Sixth Edition. www.idf.org/diabetesatlas.

Kumalaningsih, Sri. 2007. Antioksidan Alami. Surabaya: Penerbit Trubus Agrisarana

Lingga, Lanny. 2012. Bebas Diabetes Tipe 2 Tanpa Obat. Jakarta: Agromedia Pustaka

Mutiarani, Anugrah Linda. 2015. Pengaruh Pemberian Kromiun (Cr3+), Vitamin C, Dan Vitamin E Terhadap Kadar Glukosa Darah Dan Insulin Tikus Wistar Jantan (Rattus Novergicus) Yang Diinduksi Aloksan. Tesis. Universitas Airlangga.

Notoatmodjo. 2005. Metodologi Penelitian Kesehatan.Jakarta: PT. Rineka Cipta

Perkumpulan Endrokinologi Indonesia (Perkeni). 2011. Konsensus Pengendalian dan Pencegahan Diabetes Mellitus Tipe2 di Indonesia. Jakarta: PB Perkeni.

Putri, Desak Ketut (Dkk). 2014. Pengaruh Pemberian Infusum Daun Salam (Eugenia Polyantha) Terhadap Kadar Glukosa Darah Tikus (Rattus Norwegicus) Yang Diinduksi Alloksan. Veterinaria Medika Vol 7, No. 1, Pebruari 2014.

Riset Kesehatan Dasar (Riskesdas). 2013. Badan penelitian dan pengembangan kesehatan kementrian kesehatan RI. 
Schlenker, Eleanor D.; dan Roth, Sara Long. 2011. Williams' Essentials of Nutrition and Diet Therapy. USA: Mosby, Elsevier

Soekatri, M., Kartono, J. 2012. Angka Kecukupan Gizi Mineral: Kalsium, Fosfor, Magnesium, Tembaga, Kromium, Besi, Iodium, Seng, Selenium, Mangan, Flurida, Natrium dan Kalium (WNPG 2012). Jakarta

Suarsana, I. Nyoman, dkk. 2010. Sintesis Glikogen Hati dan Otot pada Tikus Diabetes yang Diberi Ekstrak Tempe. Jurnal Veteriner. ISSN: 1411-8327. Vol 11 No. 3: 190-195

Unjiati. 2014. Perbedaan Kadar Kromium dan Zinc dalam Darah Penderita Diabetes tipe 2 dan Non Diabetes di Rumah Sakit Umum Haji Surabaya. Tesis. Fakultas Kesehatan Masyarakat. Universitas Airlangga
Winarsi, Hery, dkk. 2013. Ekstrak Daun Kapulaga Menurunkan Indeks Atherogenik Dan Kadar Gula Darah Tikus Diabetes Induksi Alloxan. Jurnal Agritech. Vol. 33, No. 3, Agustus 2013.

Wulandari, Eshti dan Wirawani, Yekti. 2014. Pengaruh Pemberian Brokoli Kukus (Brassica Oleracea) Terhadap Kadar Glukosa Darah Puasa Wanita Prediabetes. Journal of Nutrition College, Volume 3, Nomor 4, Tahun 2014, Halaman 547-553.

Yuliani Dwi (Dkk). 2011. Pengaruh Pemberian Jus Brokoli (Brassica Oleracea L. Var. Italica) Terhadap Penurunan Kadar Glukosa Darah Tikus Putih (Rattus Norvegicus Strain Wistar) Model Diabetes Mellitus. Jurnal Kedokteran Brawijaya. 